\title{
Cohnella yongneupensis sp. nov. and Cohnella ginsengisoli sp. nov., isolated from two different soils
}

Correspondence

Soon-Wo Kwon

swkwon@rda.go.kr

\author{
Soo-Jin Kim, ${ }^{1}$ Hang-Yeon Weon, ${ }^{1}$ Yi-Seul Kim, ${ }^{1}$ Rangasamy Anandham, ${ }^{2}$ \\ Young-Ah Jeon, ${ }^{1}$ Seung-Beom Hong ${ }^{1}$ and Soon-Wo Kwon ${ }^{1}$
}

${ }^{1}$ Korean Agricultural Culture Collection (KACC), National Agrobiodiversity Center, Suwon 441-707,
Republic of Korea

${ }^{2}$ Department of Agricultural Microbiology, Agricultural College and Research Institute, Madurai, India

Two aerobic, Gram-positive, rod-shaped bacterial strains, $5 \mathrm{YN} 10-14^{\top}$ and $\mathrm{GR} 21-5^{\top}$, were isolated from the Yongneup wetland and ginseng soil in Korea, respectively. The two strains formed ellipsoidal or oval spores positioned centrally or paracentrally in swollen sporangia. On the basis of $16 \mathrm{~S}$ rRNA gene sequence analysis, these strains were related to members of the genus Cohnella. 16S rRNA gene sequence similarity between strains 5 YN $10-14^{\top}$ and GR21-5 ${ }^{\top}$ was $95.9 \%$. Strains 5 YN $10-14^{\top}$ and GR21-5 ${ }^{\top}$ showed, respectively, 94.3 and $95.2 \% 16 \mathrm{~S}$ rRNA gene sequence similarity to Cohnella thermotolerans CCUG $47242^{\top}, 94.6$ and $94.4 \%$ to Cohnella hongkongensis $\mathrm{HKU}^{\top}, 94.7$ and $94.7 \%$ to Cohnella laeviribosi $\mathrm{RI}^{\top}-39^{\top}$, and 95.4 and $94.8 \%$ to Cohnella phaseoli GSPC1 ${ }^{\top}$. The major fatty acids of strain $5 \mathrm{YN} 10-14^{\top}$ were anteiso$\mathrm{C}_{15: 0}(51.1 \%)$, iso- $\mathrm{C}_{16: 0}(18.5 \%)$ and $\mathrm{C}_{16: 0}(13.2 \%)$, and the major fatty acids of strain GR21-5 ${ }^{\top}$ were anteiso- $\mathrm{C}_{15: 0}(48.9 \%)$, iso- $\mathrm{C}_{16: 0}(15.0 \%)$ and iso- $\mathrm{C}_{15: 0}(12.2 \%)$. The two strains contained menaquinone with seven isoprene units (MK-7) as the predominant quinone, and diphosphatidylglycerol, phosphatidylglycerol and phosphatidylethanolamine as major polar lipids; however, strain 5 YN10-14 ${ }^{\top}$ also contained lysylphosphatidylglycerol as a major polar lipid, whereas strain GR21-5 had an unknown aminophospholipid as another major polar lipid. The DNA $G+C$ contents of strains 5 YN $10-14^{\top}$ and GR21 $-5^{\top}$ were 58.8 and $61.3 \mathrm{~mol} \%$, respectively. Based on the results of the phylogenetic and phenotypic data presented, it was concluded that the two strains represent two novel species of the genus Cohnella, for which the names Cohnella yongneupensis sp. nov. (type strain 5 YN10-14 ${ }^{\top}=$ KACC $11768^{\top}=$ DSM $18998^{\top}$ ) and Cohnella ginsengisoli sp. nov. (type strain GR21-5 ${ }^{\top}=$ KACC $11771^{\top}=\mathrm{DSM}$ $18997^{\top}$ ) are proposed.
The genus Cohnella was created to accommodate two strains, one isolated by means of hygiene control checks at a starch-producing company and the other a 'Paenibacillus hongkongensis' strain. Members of the genus Cohnella differ from those of the genus Paenibacillus on the basis of $16 \mathrm{~S}$ rRNA gene sequence analysis, polar lipid patterns and fatty acid composition (Kämpfer et al., 2006). At present, the genus Cohnella comprises four recognized species, namely Cohnella thermotolerans (the type species), C. hongkongensis (Kämpfer et al., 2006), C. laeviribosi (Cho et al., 2007)

The GenBank/EMBL/DDBJ accession numbers for the 16S rRNA gene sequences of strains 5 YN10-14 $4^{\top}$ and $\mathrm{GR} 21-5^{\top}$ are EF368008 and EF368010, respectively.

Two-dimensional thin-layer chromatograms of polar lipids of strains 5 YN $10-14^{\top}$ and GR2 $1-5^{\top}$ are available as supplementary material with the online version of this paper. and C. phaseoli (García-Fraile et al., 2008). The present study describes two novel Cohnella-like strains.

Strain $5 \mathrm{YN} 10-14^{\mathrm{T}}$ was isolated from soil of the Yongneup wetland, Republic of Korea ( $\left.38^{\circ} 12^{\prime} 53^{\prime \prime} \mathrm{N} 128^{\circ} 07^{\prime} 30^{\prime \prime} \mathrm{E}\right)$, located at 1200-1280 m above sea level. Strain GR21- $5^{\mathrm{T}}$ was isolated from ginseng soil in the Youngju region of Korea. Both of the soil samples were serially diluted with $0.85 \%$ $\mathrm{NaCl}(\mathrm{w} / \mathrm{v})$ and dilutions were plated on R2A agar (Reasoner \& Geldreich, 1985). Petri dishes were incubated at $30{ }^{\circ} \mathrm{C}$ for 3 days, and colonies were purified by using the streak plate method. Purified colonies were tentatively identified from partial $16 \mathrm{~S}$ rRNA gene sequences. The pure culture was transferred to R2A medium for further analysis.

Cell morphology was examined by using phase-contrast microscopy on cells grown on R2A for 2 days. Spore 
formation was checked after growth on R2A agar medium including $0.05 \% \mathrm{MnSO}_{4}$. Motility tests were performed on one-tenth-strength R2A medium including $0.1 \%$ agar. The tube was incubated at 20 and $30{ }^{\circ} \mathrm{C}$ for 5 days. Growth at different temperatures and $\mathrm{pH}$ was tested at $5-55{ }^{\circ} \mathrm{C}$ (in increments of $5{ }^{\circ} \mathrm{C}$ ) and $\mathrm{pH} \mathrm{3-10} \mathrm{(in} \mathrm{increments} \mathrm{of} 1 \mathrm{pH}$ unit) on R2A medium. Tolerance to $1,2,3,5$ and $7 \% \mathrm{NaCl}$ $(\mathrm{w} / \mathrm{v})$ was assessed on R2A medium. Gram staining was performed by using a Difco Gram-stain kit. Catalase activity was tested with a $3 \%(\mathrm{v} / \mathrm{v}) \mathrm{H}_{2} \mathrm{O}_{2}$ solution. Oxidase activity, and hydrolysis of casein, chitin, starch, tyrosine and carboxymethylcellulose were tested on R2A agar medium according to the methods of Smibert \& Krieg (1994). Growth and biochemical tests were also carried out by using API 20NE, API ID 32GN and API ZYM commercial kits (bioMérieux).

The two novel strains were motile, Gram-positive and rodshaped. They formed ellipsoidal or oval spores positioned centrally or paracentrally in swollen sporangia after growth for $24 \mathrm{~h}$. The strains grew on R2A and nutrient agar (Difco) but not on MacConkey agar (Difco). Strain GR21-5 grew on trypticase soy agar (TSA; Difco) whereas strain $5 \mathrm{YN} 10-14^{\mathrm{T}}$ did not. The two strains could be differentiated from each other on the basis of several physiological and biochemical properties (Table 1).

Cellular fatty acid methyl esters were prepared and analysed by GC according to the instructions of the Microbial Identification System (MIDI). Isoprenoid quinones were analysed by HPLC as described by Groth et al. (1996). Extraction and analysis of polar lipids by two-dimensional TLC were performed according to Minnikin et al. (1984). The major fatty acids of strains GR21- $5^{\mathrm{T}}$ and $5 \mathrm{YN} 10-14^{\mathrm{T}}$ were anteiso- $_{15: 0}(48.9-51.1 \%)$ and iso- $\mathrm{C}_{16: 0}(15.0-18.5 \%)$, consistent with data for recognized Cohnella species (Table 2). Characteristically, strain $5 \mathrm{YN} 10-14^{\mathrm{T}}$ did not contain iso- $\mathrm{C}_{15: 0}$, whereas strain GR21-5 $5^{\mathrm{T}}$ had a relatively high proportion $(12.2 \%)$ of this fatty acid. Strains $5 \mathrm{YN} 10-14^{\mathrm{T}}$ and GR21- $5^{\mathrm{T}}$ contained menaquinone 7 (MK-7; 91 and 93\%, respectively) as the predominant quinone, and had MK-6 (9 and $7 \%$, respectively) as a minor component. The predominant polar lipids of the two strains were diphosphatidylglycerol, phosphatidylglycerol and phosphatidylethanolamine (see Supplementary Fig. S1, available in IJSEM Online). However, strain 5 YN10-14 ${ }^{\mathrm{T}}$ contained lysylphosphatidylglycerol as a fourth major polar lipid, indicating that the polar lipid pattern of strain $5 \mathrm{YN} 10-14^{\mathrm{T}}$ was similar to those of $C$. thermotolerans and C. hongkongensis (Kämpfer et al., 2006). Strain GR2 $1-5^{\mathrm{T}}$ did not contain lysylphosphatidylglycerol, similar to data for C. phaseoli (García-Fraile et al., 2008). DNA G $+\mathrm{C}$ contents were determined by HPLC of deoxyribonucleosides as described by Mesbah et al. (1989), by using a reverse-phase column (Supelcosil LC-18 S; Supelco). The DNA G $+\mathrm{C}$ contents of strains $5 \mathrm{YN} 10-14^{\mathrm{T}}$ and GR21-5 ${ }^{\mathrm{T}}$ were 58.8 and $61.3 \mathrm{~mol} \%$, respectively.

Genomic DNA was isolated by using the method of Ausubel et al. (1987). The 16S rRNA gene was amplified and sequenced as described by Weon et al. (2005). Alignment of $16 \mathrm{~S}$ rRNA gene sequences was performed with the CLUSTAL W program (Thompson et al., 1994). Phylogenetic analysis was performed by using MEGA version 3.1 (Kumar et al., 2004). Distances with options according to the Kimura two-parameter model (Kimura, 1983) and clustering according to the neighbour-joining and maximum-parsimony methods were determined by using bootstrap values based on 1000 replicates.

The almost-complete 16S rRNA gene sequences (approximately $1385 \mathrm{bp}$ ) of the two novel isolates were used for phylogenetic analyses. The neighbour-joining tree (Fig. 1) revealed that strains $5 \mathrm{YN} 10-14^{\mathrm{T}}$ and GR21-5 ${ }^{\mathrm{T}}$ and the type strains of all recognized Cohnella species formed one compact cluster with $100 \%$ bootstrap support. The grouping of the two novel strains within the genus Cohnella was also well supported in the maximumparsimony tree (data not shown). 16S rRNA gene sequence similarity between strains $5 \mathrm{YN} 10-14^{\mathrm{T}}$ and GR21- $5^{\mathrm{T}}$ was $95.9 \%$. Strains $5 \mathrm{YN} 10-14^{\mathrm{T}}$ and GR $21-5^{\mathrm{T}}$ showed levels of 16S rRNA gene sequence similarity, respectively, of 94.3 and $95.2 \%$ to C. thermotolerans CCUG $47242^{\mathrm{T}}, 94.6$ and $94.4 \%$ to C. hongkongensis $\mathrm{HKU}^{\mathrm{T}}, 94.7$ and $94.7 \%$ to $C$. laeviribosi RI-39 ${ }^{\mathrm{T}}$ and 95.4 and $94.8 \%$ to C. phaseoli GSPC1 ${ }^{\mathrm{T}}$. However, the two strains showed 16S rRNA gene sequence similarities of less than $93 \%$ to the type strains of all recognized species of the genus Paenibacillus included in the phylogenetic analysis.

On the basis of 16S rRNA gene sequence analysis, the two novel strains were clearly affiliated with the genus Cohnella. According to the bacterial species concept and that strains showing less than $97 \% 16 \mathrm{~S}$ rRNA gene sequence similarity and levels of DNA-DNA relatedness below $70 \%$ can thus be considered as members of different species (Wayne et al., 1987), strains $5 \mathrm{YN} 10-14^{\mathrm{T}}$ and GR2 $1-5^{\mathrm{T}}$ can be considered to represent two separate species within the genus Cohnella. Phenotypically, strains $5 \mathrm{YN} 10-14^{\mathrm{T}}$ and GR $21-5^{\mathrm{T}}$ could be clearly differentiated from each other and from other recognized species of the genus Cohnella based on carbon assimilation patterns, enzyme activities, polar lipid patterns and fatty acid compositions (Tables 1 and 2). In particular, strain $5 \mathrm{YN} 10-14^{\mathrm{T}}$ was able to assimilate only a few of the test substrates.

On the basis of the data from the present polyphasic taxonomic study, strains $5 \mathrm{YN} 10-14^{\mathrm{T}}$ and GR21-5 $5^{\mathrm{T}}$ are considered to represent two novel species of the genus Cohnella, for which the names Cohnella yongneupensis sp. nov. and Cohnella ginsengisoli sp. nov., respectively, are proposed.

\section{Description of Cohnella yongneupensis sp. nov.}

Cohnella yongneupensis (yong.neup.en'sis. N.L. fem. adj. yongneupensis pertaining to Yongneup, an upland wetland of the Republic of Korea, from where the type strain was isolated). 
Table 1. Phenotypic comparison between strains $5 \mathrm{YN} 10-14^{\top}$ and GR21-5 ${ }^{\top}$ and the type strains of recognized Cohnella species

Strains: 1, 5YN10-14 ${ }^{\mathrm{T}}$ (C. yongneupensis sp. nov.); 2, GR21-5 ${ }^{\mathrm{T}}$ (C. ginsengisoli sp. nov.); 3, C. thermotolerans KACC $11643^{\mathrm{T}}$; 4 , C. hongkongensis KACC $116448^{\mathrm{T}}$; 5, C. laeviribosi KACC $13447^{\mathrm{T}}$; 6, C. phaseoli KACC $13436^{\mathrm{T}}$. Data were obtained in the present study unless indicated otherwise. All strains are positive for aesculin hydrolysis, $\beta$-galactosidase, esterase (C4), esterase lipase (C8) and naphthol-AS-BI-phosphohydrolase. All strains are negative for indole production, glucose fermentation, arginine dihydrolase, lipase (C14), valine arylamidase, cystine arylamidase, trypsin, $\alpha$ chymotrypsin, $\beta$-glucuronidase, $N$-acetyl- $\beta$-glucosaminidase and $\alpha$-mannosidase. All are unable to assimilate capric acid, adipic acid, malic acid, trisodium citrate, phenylacetic acid, itaconic acid, suberic acid, sodium malonate, sodium acetate, lactic acid, L-alanine, potassium 5-ketogluconate, 3-hydroxybenzoic acid, L-serine, propionic acid, valeric acid, L-histidine, 3-hydroxybutyric acid, 4-hydroxybenzoic acid and L-proline. +, Positive; $(+)$, weakly positive; - , negative.

\begin{tabular}{|c|c|c|c|c|c|c|}
\hline Characteristic & 1 & 2 & 3 & 4 & 5 & 6 \\
\hline Catalase/oxidase & $(+) /+$ & $+1+$ & $+1+$ & $(+) /+$ & $+1-$ & $(+) /+$ \\
\hline Nitrate reduction & - & + & - & + & - & - \\
\hline Urease & - & - & - & - & + & - \\
\hline Gelatin hydrolysis & - & - & - & - & $(+)$ & - \\
\hline \multicolumn{7}{|c|}{ Assimilation of (API $20 \mathrm{NE}$ and API ID $32 \mathrm{GN}$ ): } \\
\hline D-Glucose & - & + & + & + & + & + \\
\hline L-Arabinose & - & + & + & + & + & + \\
\hline D-Mannose & - & + & + & + & + & + \\
\hline D-Mannitol & - & + & + & + & + & - \\
\hline$N$-Acetylglucosamine & - & - & - & + & - & + \\
\hline Maltose & - & + & + & + & + & + \\
\hline Potassium gluconate & - & - & + & - & - & - \\
\hline L-Rhamnose & - & - & + & + & + & - \\
\hline D-Ribose & - & - & + & + & + & + \\
\hline Inositol & - & - & + & + & - & - \\
\hline Sucrose & - & - & + & + & + & + \\
\hline Glycogen & - & - & + & - & + & + \\
\hline Salicin & - & + & + & + & - & + \\
\hline Melibiose & - & + & + & + & + & + \\
\hline L-Fucose & - & - & + & + & + & + \\
\hline D-Sorbitol & - & - & + & + & + & - \\
\hline Potassium 2-ketogluconate & - & - & + & - & - & + \\
\hline \multicolumn{7}{|l|}{ Enzyme activities (API ZYM) } \\
\hline Alkaline phosphatase & + & - & + & + & - & - \\
\hline Leucine arylamidase & - & - & + & + & $(+)$ & $(+)$ \\
\hline Acid phosphatase & + & - & - & - & - & - \\
\hline$\alpha$-Galactosidase & + & - & + & - & + & - \\
\hline$\alpha$-Glucosidase & + & - & + & - & + & + \\
\hline$\beta$-Glucosidase & + & - & + & + & + & + \\
\hline$\alpha$-Fucosidase & + & - & - & + & - & - \\
\hline DNA G $+\mathrm{C}$ content $(\mathrm{mol} \%)$ & 58.8 & 61.3 & $59^{*}$ & $60.9 \dagger$ & $51 \neq$ & $60.3 \S$ \\
\hline
\end{tabular}

${ }^{*}$ Data from Kämpfer et al. (2006).

$\dagger$ Data from Teng et al. (2003).

$\ddagger$ Data from Cho et al. (2007).

§Data from García-Fraile et al. (2008).

Cells are motile, Gram-positive rods $(0.7 \times 2.5-3.5 \mu \mathrm{m})$ with ellipsoidal or oval spores positioned centrally or paracentrally in swollen sporangia. Growth occurs at 10$40{ }^{\circ} \mathrm{C}$ (optimum, $30{ }^{\circ} \mathrm{C}$ ), at $\mathrm{pH} 4.0-9.0$ (optimum, $\mathrm{pH} 7.0)$ and in the presence of $0-1 \%(\mathrm{w} / \mathrm{v}) \mathrm{NaCl}$. Catalase- and oxidase-positive. Carboxymethylcellulose and starch are hydrolysed, but casein, chitin and tyrosine are not. Positive for aesculin hydrolysis, but negative for nitrate reduction, indole production, glucose fermentation, arginine dihydrolase, urease and gelatin hydrolysis (API $20 \mathrm{NE}$ test strips). Does not assimilate any substrates included in the API 20NE and API ID 32GN test strips. The predominant menaquinone is MK-7. The major fatty acids are anteiso- $\mathrm{C}_{15: 0}$, iso- $\mathrm{C}_{16: 0}$ and $\mathrm{C}_{16: 0}$. The predominant polar lipids are diphosphatidylglycerol, phosphatidylglycerol, phosphatidylethanolamine and lysylphosphatidylglycerol. The DNA $\mathrm{G}+\mathrm{C}$ content of the type strain is $58.8 \mathrm{~mol} \%$ (HPLC). 
Table 2. Cellular fatty acid compositions of strains $5 \mathrm{YN} 10-14^{\top}$ and GR21-5 ${ }^{\top}$ and the type strains of recognized Cohnella species

Strains: 1, 5YN10-14 ${ }^{\mathrm{T}}$ (C. yongneupensis sp. nov.); 2, GR21-5 ${ }^{\mathrm{T}}$ (C. ginsengisoli sp. nov.); 3, C. thermotolerans KACC $11643^{\mathrm{T}}$; 4, C. hongkongensis KACC $11644^{\mathrm{T}} ; 5$, C. laeviribosi KACC $13447^{\mathrm{T}} ; 6$, C. phaseoli KACC $13436^{\mathrm{T}}$. All data were obtained in the present study. All strains were cultivated on R2A medium at $30{ }^{\circ} \mathrm{C}$ for 3 days before harvesting cell mass. Values are percentages of the total fatty acids. - , Not detected or $<1 \%$.

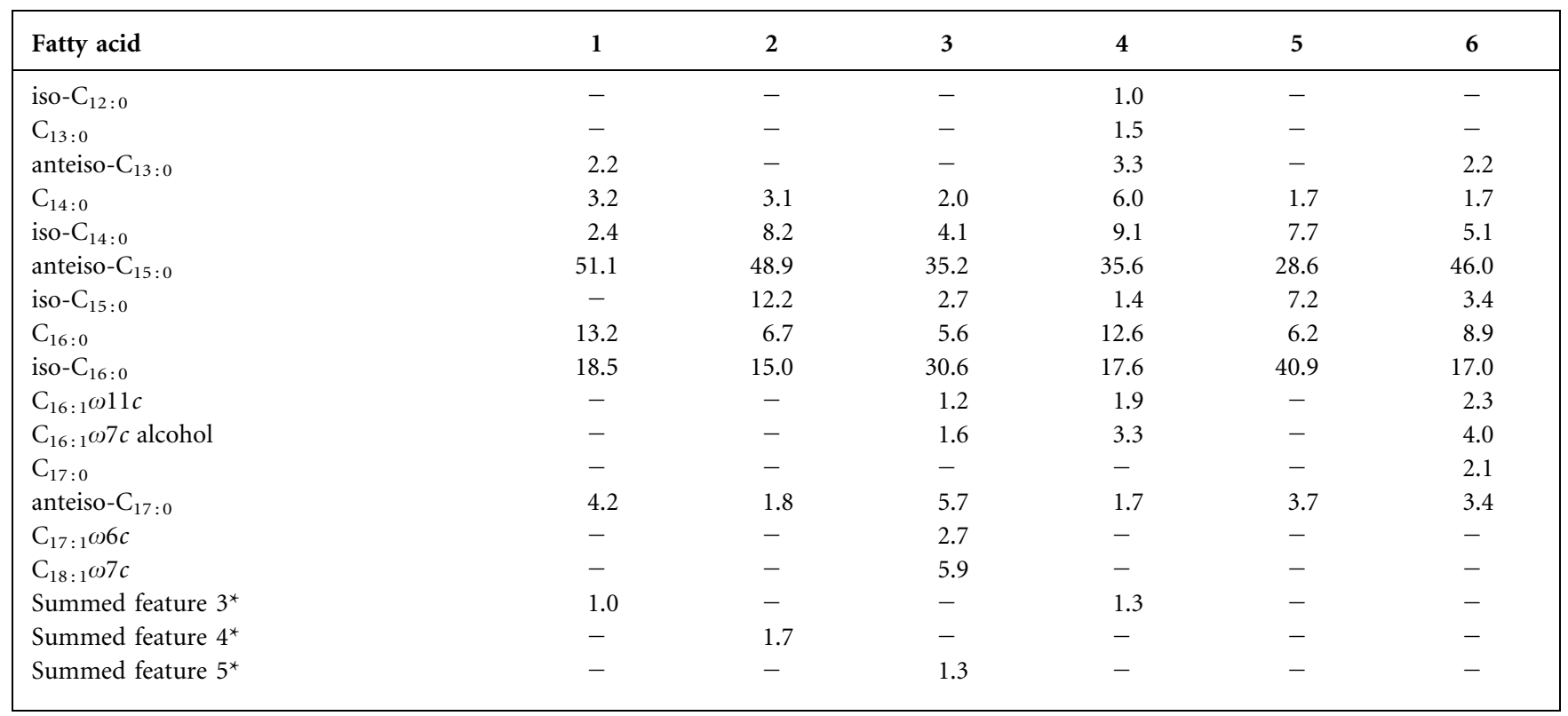

${ }^{*}$ Summed features represent groups of two fatty acids that could not be separated by GLC with the MIDI system. Summed feature 3 comprises $\mathrm{C}_{16: 1} \omega 7 c$ and/or iso- $\mathrm{C}_{15: 0} 2-\mathrm{OH}$; summed feature 4 comprises iso- $\mathrm{C}_{17: 1} \mathrm{I}$ and/or anteiso- $\mathrm{C}_{17: 1} \mathrm{~B}$; summed feature 5 comprises anteiso- $\mathrm{C}_{18: 0}$ and/ or $\mathrm{C}_{18: 2} \omega 6,9 c$.

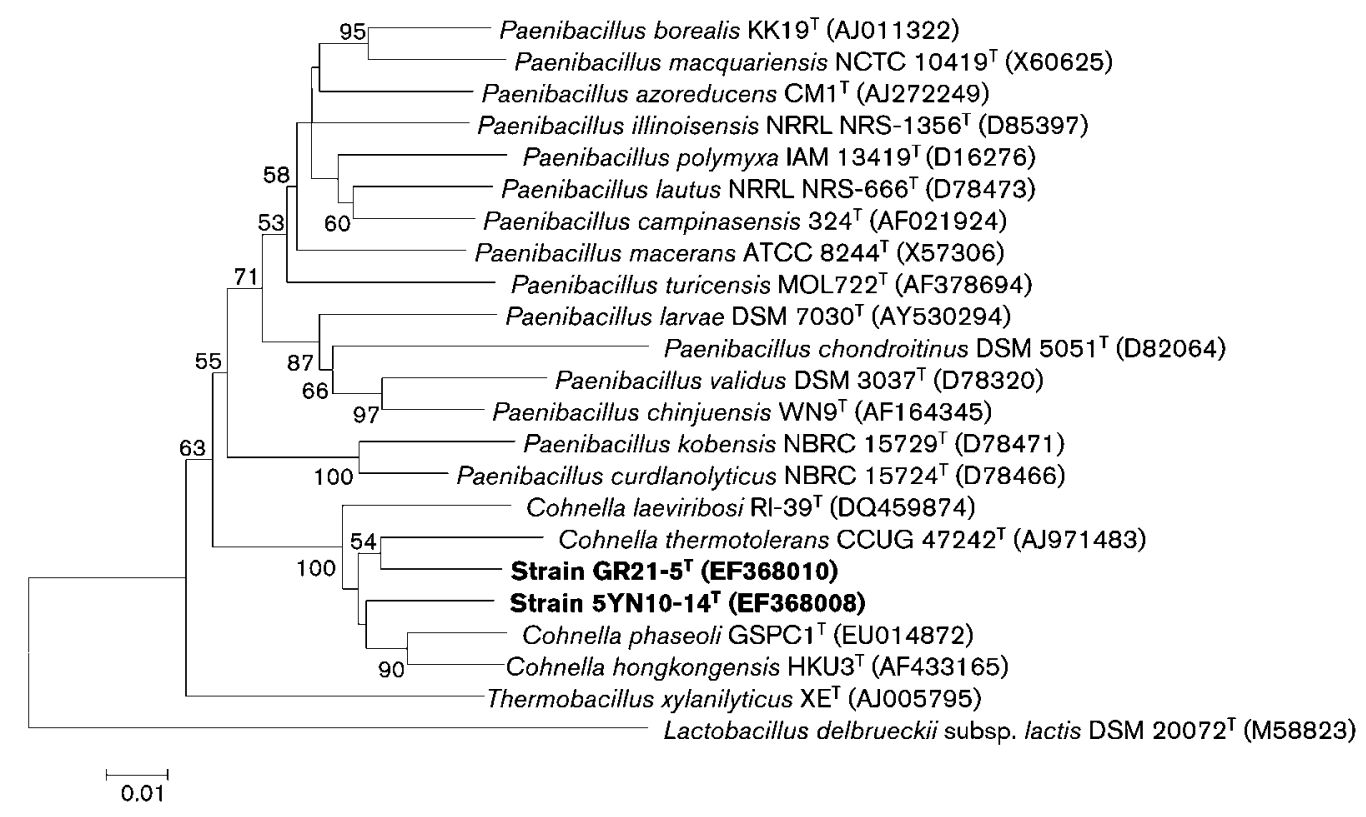

Fig. 1. Neighbour-joining tree based on $16 \mathrm{~S}$ rRNA gene sequences showing the phylogenetic positions of strains 5 YN10-14 and GR2 $1-5^{\top}$ and the type strains of closely related species. Numbers at nodes indicate the percentage of bootstrap support based on a neighbour-joining analysis of 1000 resampled datasets; values below $50 \%$ are not shown. Bar, 0.01 substitutions per nucleotide position. 
The type strain, $5 \mathrm{YN} 10-14^{\mathrm{T}} \quad\left(=\mathrm{KACC} \quad 11768^{\mathrm{T}}=\mathrm{DSM}\right.$ $18998^{\mathrm{T}}$ ), was isolated from the Yongneup wetland in the Republic of Korea.

\section{Description of Cohnella ginsengisoli sp. nov.}

Cohnella ginsengisoli (gin.sen.gi.so'li. N.L. n. ginsengum ginseng; L. n. solum soil; N.L. gen. n. ginsengisoli of the soil of a ginseng field, the source of the type strain).

Cells are motile, Gram-positive rods $(1.0 \times 2.0-3.0 \mu \mathrm{m})$ with ellipsoidal or oval spores positioned centrally or paracentrally in swollen sporangia. Growth occurs at $10-40{ }^{\circ} \mathrm{C}$ (optimum, $30{ }^{\circ} \mathrm{C}$ ), at $\mathrm{pH}$ 5.0-9.0 (optimum, pH 7.0) and in the presence of $0-2 \%(\mathrm{w} / \mathrm{v}) \mathrm{NaCl}$. Catalase- and oxidasepositive. Starch is hydrolysed, but casein, carboxymethylcellulose, chitin and tyrosine are not. Positive for nitrate reduction and aseculin hydrolysis, but negative for indole production, glucose fermentation, arginine dihydrolase, urease and gelatin hydrolysis (API 20NE test strips). Assimilates D-glucose, L-arabinose, D-mannose, D-mannitol, maltose, salicin and melibiose, but not $\mathrm{N}$-acetylglucosamine, potassium gluconate, capric acid, adipic acid, malic acid, trisodium citrate, phenylacetic acid, L-rhamnose, D-ribose, inositol, sucrose, itaconic acid, suberic acid, sodium malonate, sodium acetate, lactic acid, L-alanine, potassium 5-ketogluconate, glycogen, 3-hydroxybenzoic acid, L-serine, L-fucose, D-sorbitol, propionic acid, valeric acid, L-histidine, potassium 2-ketogluconate, 3-hydroxybutyric acid, 4hydroxybenzoic acid or L-proline (API 20NE and API ID $32 \mathrm{GN}$ test strips). The predominant menaquinone is MK-7. The major fatty acids are anteiso- $\mathrm{C}_{15: 0}$, iso- $\mathrm{C}_{16: 0}$ and iso$\mathrm{C}_{15: 0}$. The predominant polar lipids are diphosphatidylglycerol, phosphatidylglycerol, phosphatidylethanolamine and an unknown aminophospholipid. The DNA G + C content of the type strain is $61.3 \mathrm{~mol} \%$ (HPLC).

The type strain, GR21-5 $5^{\mathrm{T}}\left(=\right.$ KACC $11771^{\mathrm{T}}=$ DSM $\left.18997^{\mathrm{T}}\right)$, was isolated from ginseng soil in the Youngju region of the Republic of Korea.

\section{Acknowledgements}

This work was supported by the National Academy of Agricultural Science (NAAS), Rural Development Administration, Republic of Korea.

\section{References}

Ausubel, F. M., Brent, R., Kingston, R. E., Moore, D. D., Seidman, J. G., Smith, J. A. \& Struhl, K. (editors) (1987). Current Protocols in Molecular Biology. New York: Wiley.
Cho, E. A., Lee, J. S., Lee, K. C., Jung, H. C., Pan, J. G. \& Pyun, Y. R. (2007). Cohnella laeviribosi sp. nov., isolated from a volcanic pond. Int J Syst Evol Microbiol 57, 2902-2907.

Garcia-Fraile, P., Velázquez, E., Mateos, P. F., Martínez-Molina, E. \& Rivas, R. (2008). Cohnella phaseoli sp. nov., isolated from root nodules of Phaseolus coccineus in Spain, and emended description of the genus Cohnella. Int J Syst Evol Microbiol 58, 1855-1859.

Groth, I., Schumann, P., Weiss, N., Martin, K. \& Rainey, F. A. (1996). Agrococcus jenensis gen. nov., sp. nov., a new genus of actinomycetes with diaminobutyric acid in the cell wall. Int J Syst Bacteriol 46, 234239.

Kämpfer, P., Rosselló-Mora, R., Falsen, E., Busse, H. J. \& Tindall, B. J. (2006). Cohnella thermotolerans gen. nov., sp. nov., and classification of 'Paenibacillus hongkongensis' as Cohnella hongkongensis sp. nov. Int J Syst Evol Microbiol 56, 781-786.

Kimura, M. (1983). The Neutral Theory of Molecular Evolution. Cambridge: Cambridge University Press.

Kumar, S., Tamura, K. \& Nei, M. (2004). MEGA3: integrated software for molecular evolutionary genetics analysis and sequence alignment. Brief Bioinform 5, 150-163.

Mesbah, M., Premachandran, U. \& Whitman, W. B. (1989). Precise measurement of the $\mathrm{G}+\mathrm{C}$ content of deoxyribonucleic acid by high-performance liquid chromatography. Int J Syst Bacteriol 39, 159167.

Minnikin, D. E., O'Donnell, A. G., Goodfellow, M., Alderson, G., Athalye, M., Schaal, A. \& Parlett, J. H. (1984). An integrated procedure for the extraction of bacterial isoprenoid quinones and polar lipids. J Microbiol Methods 2, 233-241.

Reasoner, D. J. \& Geldreich, E. E. (1985). A new medium for the enumeration and subculture of bacteria from potable water. Appl Environ Microbiol 49, 1-7.

Smibert, R. M. \& Krieg, N. R. (1994). Phenotypic characterization. In Methods for General and Molecular Bacteriology, pp. 607-654. Edited by P. Gerhardt, R. G. E. Murray, W. A. Wood \& N. R. Krieg. Washington, DC: American Society for Microbiology.

Teng, J. L., Woo, P. C., Leung, K. W., Lau, S. K., Wong, M. K. \& Yuen, K. Y. (2003). Pseudobacteraemia in a patient with neutropenic fever caused by a novel paenibacillus species: Paenibacillus hongkongensis sp. nov. Mol Pathol 56, 29-35.

Thompson, J. D., Higgins, D. G. \& Gibson, T. J. (1994). CLUSTAL W: improving the sensitivity of progressive multiple sequence alignment through sequence weighting, position-specific gap penalties and weight matrix choice. Nucleic Acids Res 22, 4673-4680.

Wayne, L. G., Brenner, D. J., Colwell, R. R., Grimont, P. A. D., Kandler, O., Krichevsky, M. I., Moore, L. H., Moore, W. E. C., Murray, R. G. E. \& other authors (1987). International Committee on Systematic Bacteriology. Report of the ad hoc committee on reconciliation of approaches to bacterial systematics. Int $J$ Syst Bacteriol 37, 463-464.

Weon, H.-Y., Kim, B.-Y., Kwon, S.-W., Park, I.-C., Cha, I.-B., Tindall, B. J., Stackebrandt, E., Trüper, H. G. \& Go, S.-J. (2005). Leadbetterella byssophila gen. nov., sp. nov., isolated from cotton-waste composts for the cultivation of oyster mushroom. Int J Syst Evol Microbiol 55, 2297-2302. 